\title{
Study on Self-Compacting Concrete with Sustainable Materials
}

\author{
Alagar Leelavathi ${ }^{1 *}$, K. Sudalaimani ${ }^{2}$ \\ 'Department of Civil Engineering, Alagappa Chettiar Government College of Engineering and Technology, \\ Karaikudi, Tamilnadu, India-630003 \\ ${ }^{2}$ Department of Civil Engineering, Thiagarajar College of Engineering, Madurai, Tamilnadu, India-625015
}

Received: 24 January 2021

Accepted: 15 April 2021

\begin{abstract}
The current study experimentally probes into the possibilities of using M-sand with ground granulated blast furnace slag in Self-Compacting Concrete (SCC). The Ground granulated blast furnace slag is a by-product material obtained through the blast-furnaces used to make iron. Dumping of this waste material near to the industries creates land pollution. The research analyses the potential of GGBS when it is added at 10,20,30, 40 and $50 \%$ by weight instead of cement in the preparation of SCC. M-sand was also used instead of natural fine aggregate at 20, 40, 60 and $80 \%$ by weight. An evaluation of the Fresh and hardened properties of the samples was also done. Efforts were made to study in detail the microstructure of the SCC specimens by subjecting it to Scanning Electron Microscope (SEM) and Energy Dispersive X ray Analyzer (EDAX) analysis. In order to achieve the required flow parameters, superplasticizer was added. Likewise, fly ash (FA) was employed as an additional mineral admixture to the components. The results revealed that the inclusion of M-sand with the GGBS increases the compressive strength of SCC to about 55.55 MPa with 20\% replacement of GGBS which helps to reduce the $\mathrm{CO}_{2}$ emission due to cement industries.
\end{abstract}

Keywords: GGBS, M-sand, SCC, SEM, sustainable materials

\section{Introduction}

The social and economical developments are the key for the human growth.Industrial growth benefit the society and degrade the environment by producing wastes. Disposal of the waste directly pollute land and indirectly pollute water and it turns as toxic. Most of the industrial processes release useful products along with harmful pollutants and waste products. The construction

*e-mail: leelaaccet2007@gmail.com industry is also one among major source of pollution, which contributes $4 \%$ of particulate emissions, increased water and noise pollution. Particularly in the cement industries, when the calcium carbonate is heated to very high temperature to produce lime, the carbon dioxide is also released which contributes directly to green house gases. The industry also uses non renewable energy sources like fossil fuels. The researchers suggest that policy makers should arrive at a suitable level of carbon tax to promote the smooth progress of construction projects and to improve the emission reduction effect [1]. The concrete is said to be sustainable material when it is produced with less energy consumption. It must 
produce durable structures using only little energy. It must use recyclable and green materials. This goal can be achieved by using industrial by- products in concrete [2-4]. In order to achieve the goal of sustainable development in concrete production this study examines the possibility of using ground granulated blast furnace slag (GGBS) in concrete as a partial replacement of cement. The cement consumption can be reduced by using these industrial by products like GGBS which contributes directly to reduced carbon emissions. Also the use of M-Sand (Manufactured Sand) as a partial and full replacement instead of natural sand helps in producing green concrete. When we use these kinds of unconventional materials in concrete it is necessary to study the strength and durability of such concrete. This research paper investigates the fresh and hardened properties of Industrial waste GGBS, fly ash and M-Sand admixed self-compacting green concrete.

GGBS is a by-product material obtained through the blast-furnaces used to make iron. GGBS is being used as a successful alternative replacement material for cement in construction industries all over the world. GGBS has been successfully used in self- compacting concrete. Addition of GGBS in self-compacting concrete provides many benefits related to increasing its compactability, consistency and retaining it for a longer time [5]. Many researches had been done using GGBS and the results shown that self-compacting concretes with GGBS at various replacement levels achieved higher strengths ranging from 30 to $100 \mathrm{MPa}[6]$. GGBFS enhances the service life of concrete structures and improving the durability of concrete.

The consumption of natural sand is high, to accomplish the rapid infrastructural growth. This situation leads developing countries like India to face the scarcity of good quality natural sand in near future. In India natural sand deposits are being depleted and create many environment degradations. In order to overcome the scarcity of natural resources and to protect the environment researches are done to suggest the reasonably priced and easily available alternative materials. Many alternative materials have already been used instead of natural sand e.g. Manufactured sand, copper slag, fly ash, slag, limestone, and siliceous stone powder and they are used in concrete mixtures as a partial replacement [7, 8]. Among these materials manufactured sand proved as a suitable substitute for natural river sand by many researchers [8]. The M-sand is produced by crushing rock deposits. This alternative material can be produced abundantly and it satisfies the requirements of fresh and hardened concrete properties similar to fine aggregate. From the literature the researchers made a study on SCC using M-sand and proved that Manufactured sand is a suitable replacement material for river sand and it is suitable for the development of SCC due to increase in paste volume [8].

According to Karmaegam et al. fresh and hardened properties of SCC can be improved by adding fly ash to self-compacting concrete (SCC). Fly ash is the most preferable admixture for SCC due to the spherical nature of particles. To achieve the maximum workability of SCC fly ash is also added in the powder content [9]. Further, the optimum amount of Fly ash that can be mixed was found to be up to 30 percent of Plain Cement by mass. Two benefits were found by the researchers due to the addition of Fly ash. One is it improves the rheological characteristics of SCC mixture and the second one is because of its small spherical shape it reduces the demand of water in the mix [5, 10].

This work is aimed at developing a concrete using GGBS, as a replacement material for the cement in self-compacting concrete containing M-sand, which is partially replaced for fine aggregate. The SEM results show that there is a potential future for the byproduct and an alternative material, namely GGBS to be used as admixture in SCC. The study attempts to find the impact of using GGBS and M-sand in preparing SCC. This study reveals the experimental result of the impact of the above mixture on SCC's fresh and hardened properties. The research analyses the potential of GGBS when it is added at 10, 20, 30, 40 and $50 \%$ by weight instead of cement in the preparation of SCC. M-sand was also used instead of natural fine aggregate at 20, 40,60 and $80 \%$ by weight. In all mixes $20 \%$ of fly ash was used as additional filler which enhances the flow properties of SCC.

\section{Materials and Methods}

In this investigation Ordinary Portland cement of 53 grade was used as per IS code. The fineness of the cement was $1 \%$ by sieve test and the fineness of cement by Blaine's air permeability was $330 \mathrm{~m}^{2} / \mathrm{kg}$ and the specific gravity was 3.15 . The preferred size for the structures having congested reinforcement is an aggregate size of $10 \mathrm{~mm}$. Further, the preferred aggregate should be of well graded cubical or round shaped. The maximum $15 \mathrm{~mm}$ size was selected to reduce the difficulties of producing, mixing and placing concrete and to prevent segregation of aggregate in fresh concrete. In this work the crushed stone aggregate of size $12.5 \mathrm{~mm}$ to $6.3 \mathrm{~mm}$ has been utilized. The specific gravity and Bulk density of the coarse aggregate used were 2.73 and $1463 \mathrm{~kg} / \mathrm{m}^{3}$ respectively. The fineness modulus was 6.89 . The fine aggregates used were Ordinary river sand and M-sand. The ordinary river sand has specific gravity of 2.56 and fineness modulus of 2.79. Rock and gravel crushed to the required grain size is called as M-sand. The specific gravity of $\mathrm{M}$-sand used is 2.53. The Superplasticizer was used to obtain the flow properties. It is based on the selected sulphonated naphthalene polymers. The commercial product name is Conplast SP430. There are two mineral admixtures which were utilized in this work such as GGBS and fly ash. The specific gravity of the GGBS and fly ash were 2.85 and 2.16 respectively. The quality 
of slag fulfills the requirements of IS 12089-1987 [11]. The GGBS obtained from Astra chemicals, Chennai India was used. The fineness of GGBS was $390 \mathrm{~m}^{2} / \mathrm{kg}$. The fineness of fly ash was $325 \mathrm{~m}^{2} / \mathrm{kg}$. Class F fly ash was acquired from "Mettur Thermal Power Plant" close to Mettur Dam, Tamilnadu, India.

\section{Mixture Proportions}

The mix proportion calculated for this study is 1:1.54:1.20 (Powder: fine aggregates: coarse aggregates) with water/powder ratio of 1.05 by volume. Here powder content refers to cement and fly ash. The above ratio was used to prepare the M50 grade concrete.

The mix proportion was calculated based on particle packing and specific gravity basis. The powder content includes cement, fly ash and Ground Granulated Blast furnace Slag. Generally fly ash content of 25 to 50 percent can be used as per IS10262:2019 [12]. The fly ash replacement is limited to $20 \%$ in all mixes including control mix so as to find the benefits of industrial waste such as GGBS. Designation of $\mathrm{G}_{10} \mathrm{M}_{20}$ used in this study represents that GGBS content of $10 \%$ and manufactured sand $20 \%$. All the mix proportions are represented in a similar way. Since the workability was not obtained beyond an $\mathrm{M}$-sand content of $80 \%$ the mixes were prepared only up to $80 \%$ of M-sand content.

\section{Procedure of Testing}

The fresh properties were analysed by conducting several tests such as slump flow, T 50 slump flow, V-funnel, J-ring Test, L box, and U-box in agreement with the procedure suggested by the EFNARC Guidelines [13]. As per IS: 516 reaffirmed in 1999, the concrete cubes were cast to determine the compressive strength of concrete. The size of the concrete cube specimens were $150 \times 150 \times 150 \mathrm{~mm}$. The total number of specimens was 180 (3 specimens for each mix on 7 and 28 days of testing). After $24 \mathrm{hrs}$ the specimens were de-molded. Further the concrete specimens thus made subjected to water curing for 7 and 28 days. Then these specimens were subjected to the test compressive strength.

The splitting tensile strength of concrete was assessed for the specimens having 20\% (optimum content) of GGBS in all proportions of M-sand. The size of the cylindrical specimen is $150 \mathrm{~mm} \times 300 \mathrm{~mm}$. After $24 \mathrm{hrs}$ the specimens were demolded. Further, the concrete specimens were subjected to water curing for 28 days and test of splitting tensile strength. The two tests were done in compression testing machine of $2,000 \mathrm{kN}$ capacity.

\section{SEM- EDAX Analyses of GGBS}

The SEM study was performed using Joel $5600 \mathrm{LV}$ Scanning Electron Microscope. The morphology of the GGBS was observed with the SEM (Fig. 1). The GGBS consists of rough and dense micro sized angular particles. The particle size distribution ranges between approximately 1 and 60 microns. Approximately $40-50 \%$ of the particles ( $\%$ by volume) are sized close to 1 micron. The SEM and EDAX analysis of GGBS sample is shown in Fig. 1(a, b). The mineralogical composition of two admixtures used is given in Table 1. The fly ash that is used in the current study was tested and found to have the above composition as per the work done by Karmegam et al. [9]. GGBS and fly ash has composition of silica, alumina, calcium oxide and iron content. The quantitative elemental composition of the GGBS evidenced the presence of high amount of Calcium and Silicon and small amounts of Sulphur.

\section{Results and Discussion}

\section{Fresh Concrete Properties}

Several workability tests of SCC mixes were done and the results are in Table 2 and all the SCC
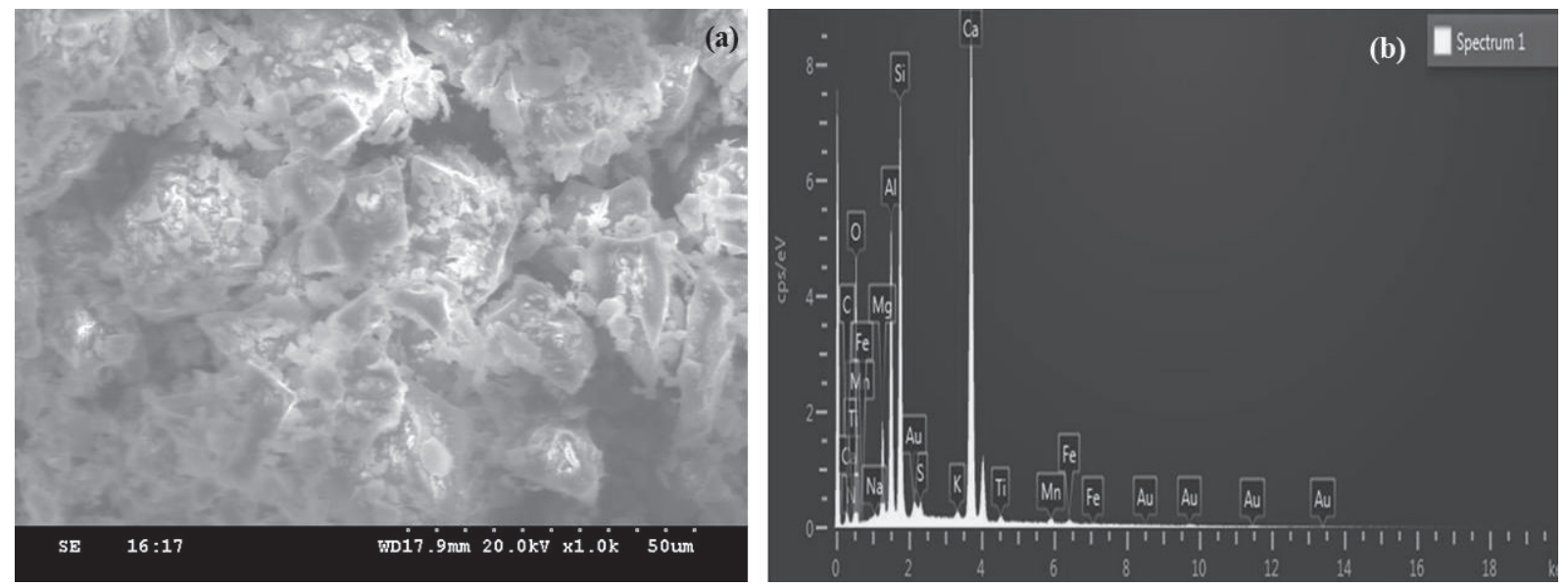

Fig. 1. a) SEM Image of GGBS sample, b). EDAX Image of GGBS sample. 
Table 1. Composition of Portland cement and Mineral Admixtures.

\begin{tabular}{|c|c|c|c|c|}
\hline S. No & Composition (\%) & Cement (\%) IS: 12269-1987) & Ground Granulated Blast furnace slag (\%) & Fly ash (\%) \\
\hline 1 & $\mathrm{CaO}$ & 62.11 & 35.37 & 1.42 \\
\hline 2 & $\mathrm{SiO}_{2}$ & 21.04 & 33.05 & 39.34 \\
\hline 3 & $\mathrm{Al}_{2} \mathrm{O}_{3}$ & 5.02 & 20 & 51.13 \\
\hline 4 & $\mathrm{Fe}_{2} \mathrm{O}_{3}$ & 3.12 & 1.00 & 5.23 \\
\hline 5 & $\mathrm{MgO}$ & 2.44 & 7.603 & - \\
\hline 6 & Loss on ignition & 1.2 & 0.26 & 1 \\
\hline 7 & Insoluble residue & - & 0.49 & 0.2 \\
\hline 8 & Glass content & - & 91 & - \\
\hline
\end{tabular}

Table 2. Results of workability tests of SCC mixes.

\begin{tabular}{|c|c|c|c|c|}
\hline Sl. No & Mix code & Slump Flow Spread Diameter (mm) & $\mathrm{T}_{50}$ Slump Flow (sec) & V-Funnel Test (sec) \\
\hline & Typical Range & $650-800$ & $2-7$ & $6-12$ \\
\hline 1 & Control Concrete $/ \mathrm{G}_{0} \mathrm{M}_{0}$ & 680 & 3 & 12 \\
\hline 2 & $\mathrm{G}_{10} \mathrm{M}_{0}$ & 690 & 4 & 11 \\
\hline 3 & $\mathrm{G}_{20} \mathrm{M}_{0}$ & 760 & 4 & 10 \\
\hline 4 & $\mathrm{G}_{30} \mathrm{M}_{0}$ & 765 & 3 & 9 \\
\hline 5 & $\mathrm{G}_{40} \mathrm{M}_{0}$ & 770 & 3 & 8 \\
\hline 6 & $\mathrm{G}_{50} \mathrm{M}_{0}$ & 780 & 3 & 7 \\
\hline 7 & $\mathrm{G}_{0} \mathrm{M}_{20}$ & 720 & 4 & 10 \\
\hline 8 & $\mathrm{G}_{10} \mathrm{M}_{20}$ & 720 & 3 & 9 \\
\hline 9 & $\mathrm{G}_{20} \mathrm{M}_{20}$ & 775 & 2 & 8 \\
\hline 10 & $\mathrm{G}_{30} \mathrm{M}_{20}$ & 780 & 3 & 7 \\
\hline 11 & $\mathrm{G}_{40} \mathrm{M}_{20}$ & 790 & 4 & 8 \\
\hline 12 & $\mathrm{G}_{50} \mathrm{M}_{20}$ & 790 & 4 & 8 \\
\hline 13 & $\mathrm{G}_{0} \mathrm{M}_{40}$ & 780 & 4 & 11 \\
\hline 14 & $\mathrm{G}_{10} \mathrm{M}_{40}$ & 790 & 3 & 10 \\
\hline 15 & $\mathrm{G}_{20} \mathrm{M}_{40}$ & 792 & 2 & 9 \\
\hline 16 & $\mathrm{G}_{30} \mathrm{M}_{40}$ & 795 & 3 & 8 \\
\hline 17 & $\mathrm{G}_{40} \mathrm{M}_{40}$ & 795 & 3 & 7 \\
\hline 18 & $\mathrm{G}_{50} \mathrm{M}_{40}$ & 798 & 3 & 6 \\
\hline 19 & $\mathrm{G}_{0} \mathrm{M}_{60}$ & 680 & 5 & 9 \\
\hline 20 & $\mathrm{G}_{10} \mathrm{M}_{60}$ & 720 & 5 & 8 \\
\hline 21 & $\mathrm{G}_{20} \mathrm{M}_{60}$ & 790 & 4 & 7 \\
\hline 22 & $\mathrm{G}_{30} \mathrm{M}_{60}$ & 800 & 4 & 6 \\
\hline 23 & $\mathrm{G}_{40} \mathrm{M}_{60}$ & 810 & 6 & 7 \\
\hline 24 & $\mathrm{G}_{50} \mathrm{M}_{60}$ & 815 & 6 & 7 \\
\hline 25 & $\mathrm{G}_{0} \mathrm{M}_{80}$ & 700 & 6 & 9 \\
\hline 26 & $\mathrm{G}_{10} \mathrm{M}_{80}$ & 710 & 6 & 9 \\
\hline 27 & $\mathrm{G}_{20} \mathrm{M}_{80}$ & 715 & 5 & 10 \\
\hline
\end{tabular}


Table 2. Continued.

\begin{tabular}{|c|c|c|c|c|}
\hline 28 & $\mathrm{G}_{30} \mathrm{M}_{80}$ & 730 & 4 & 12 \\
\hline 29 & $\mathrm{G}_{40} \mathrm{M}_{80}$ & 735 & 5 & 10 \\
\hline 30 & $\mathrm{G}_{50} \mathrm{M}_{80}$ & 750 & 4 & 9 \\
\hline
\end{tabular}

Mixes satisfied the EFNARC (2005) regulations [13]. Research works show that 15 to $45 \%$ of GGBS replacement results in higher slump flow, passing ability and lowers V-funnel flow time and T50 slump flow. Addition of GGBS from $25 \%$ to $100 \%$ has improved SCC's fluidity behaviors such as flow ability, passing ability and filling ability. The usage of GGBS between $25 \%$ to $50 \%$ is also recommended as cement replacements in the production of SCC [14]. Nanthagopalan et al., concluded that M-sand is useful for the development of SCC as the high fines present in it increases the paste volume, even though it increases the water demand [8]. Ramanathan et al. obtained better slump flow values while using the blast furnaces [15]. The slump flow values were found between 680 to $820 \mathrm{~mm}$ for all SCC mixes. This indicates that all SCC mixes possess good deformability and showed no signs of segregation. The requirement of Super Plasticizer varied based on the target slump flow value of each SCC mix. There is a considerable increase in the amount of Super Plasticizer with the increasing contents of M- sand and GGBS.

Lowest workability was obtained for mix containing percentage of GGBS as $20 \%$ and $20 \%$ M-Sand. Maximum workability was obtained for mix containing percentage of GGBS as $40 \%$ and $60 \%$ M-Sand. Workability improved with increase in GGBS and M-Sand content.

The effect of GGBS on Slump flow value is in Fig. 2. The inclusion of mineral admixtures like GGBS and fly ash increases the paste volume. This increase in paste volume reduces the friction between the aggregate and paste particles and hence the fluidity of the mix is good when the GGBS content is increasing.
The T500 time is the time necessary to reach 500 mm slump flow. It otherwise indicates the viscosity of the concrete - the higher the time to reach $500 \mathrm{~mm}$, the higher the viscosity. The T500 time is the time necessary to reach $500 \mathrm{~mm}$ slump flow. It otherwise indicates the viscosity of the concrete.

All mixtures show that the measured T500 time is from 2 to $6 \mathrm{~s}$, falling in the acceptance range of SCC $(2-7 \mathrm{~s}$, ) as per EFNARC. While comparing the control concrete, the $60 \% \mathrm{M}$-sand replaced mixtures have taken a longer time to achieve a slump flow of $500 \mathrm{~mm}$. The $\mathrm{V}$-funnel time is in the range of 6-12 s. The V-funnel time significantly increased with an increase in GGBS replacement and M-sand replacement levels. The increase in flow time of the mix indicates segregation. The test again was implemented by permitting the concrete to have a rest in the funnel for $5 \mathrm{~min}$. No segregation or bleeding was observed on all SCC mixtures. The characteristics of materials such as particles shape, particle-size distribution, and the smoothness of surface textures influence the workability and water demand of the concrete mix [16].

\section{Mechanical Properties}

\section{Compressive Strength}

From the experimental results, it is ascertained that maximum strength can be attained at a particular level of GGBS replacement and M-sand replacement level.

The variation of compressive strength at 7 days, 28 days for all mixes has been shown in Fig 3 . In Table 3, the results of compressive strength and split tensile strength are shown. The addition of GGBS and

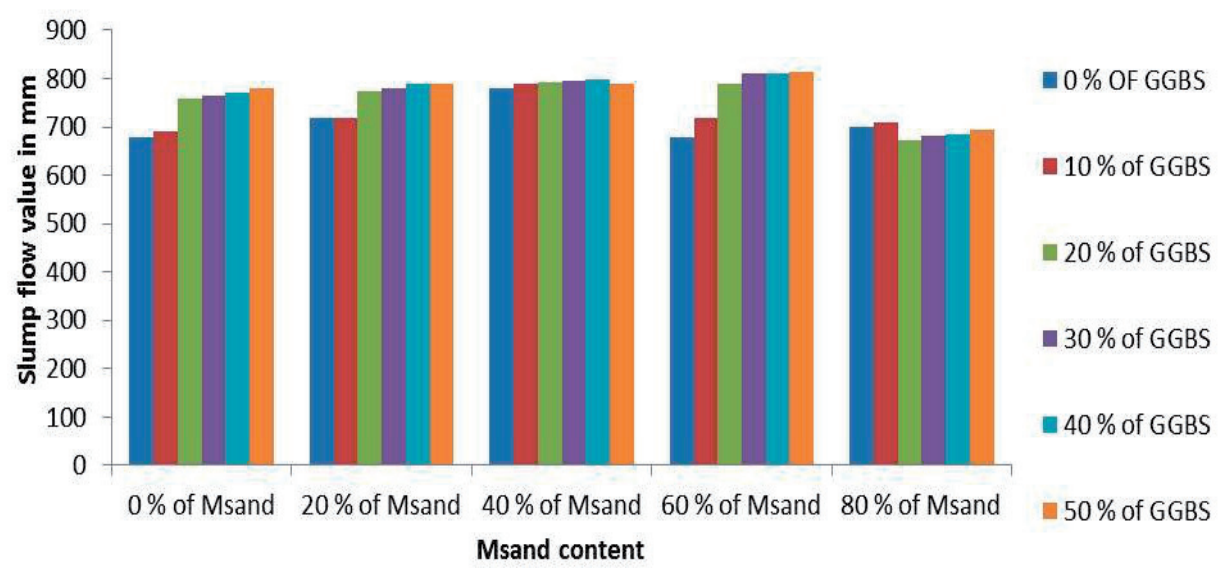

Fig. 2. Effect of GGBS on Slump flow value. 


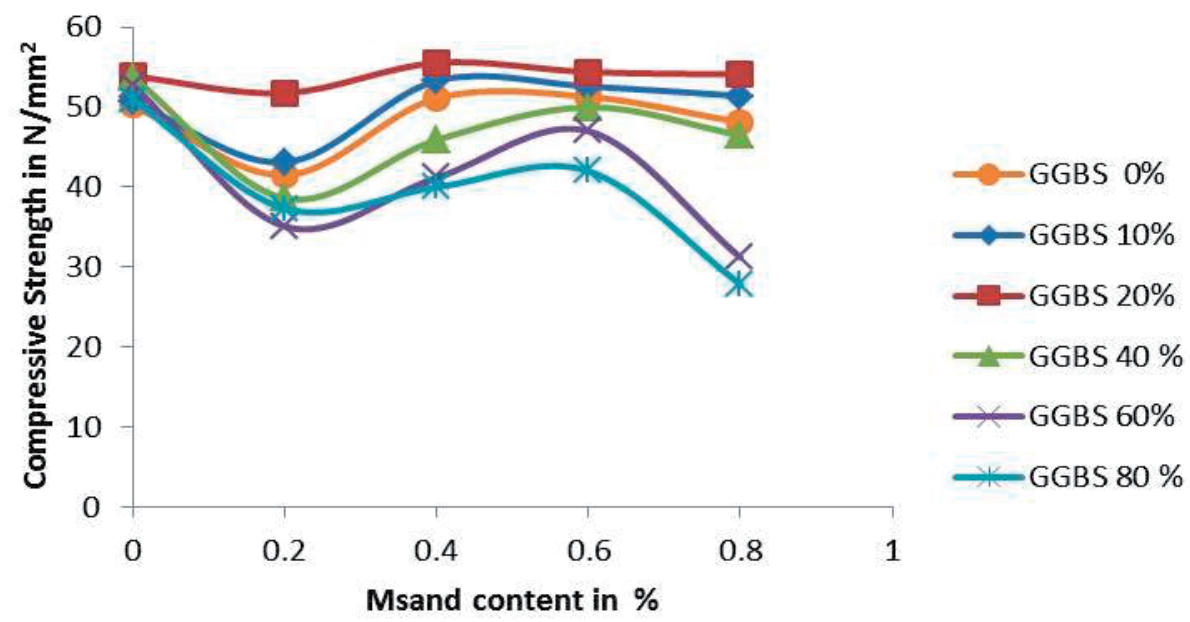

Fig. 3. Compressive Strength result.

Table 3. Mechanical Properties of SCC with GGBS and M-sand.

\begin{tabular}{|c|c|c|c|c|c|}
\hline \multirow{2}{*}{ S. No } & \multirow{2}{*}{ Mix Designation } & \multicolumn{2}{|c|}{ Compressive Strength $\left(\mathrm{N} / \mathrm{mm}^{2}\right)$} & \multirow{2}{*}{$\begin{array}{l}\text { Percentage increase or } \\
\text { decrease at } 28 \text { days }\end{array}$} & \multirow{2}{*}{$\begin{array}{l}\text { Splitting tensile strength at } \\
28 \text { days }\left(\mathrm{N} / \mathrm{mm}^{2}\right)\end{array}$} \\
\hline & & 7 days & 28 Days & & \\
\hline 1 & Control Concrete/ $\mathrm{G}_{0} \mathrm{MS}_{0}$ & 33.33 & 50.22 & - & 5.45 \\
\hline 2 & $\mathrm{G}_{10} \mathrm{MS}_{0}$ & 34.05 & 50.66 & +1.87 & \\
\hline 3 & $\mathrm{G}_{20} \mathrm{MS}_{0}$ & 37.18 & 53.88 & +7.28 & 5.65 \\
\hline 4 & $\mathrm{G}_{30} \mathrm{MS}_{0}$ & 36.20 & 53.11 & +5.75 & \\
\hline 5 & $\mathrm{G}_{40} \mathrm{MS}_{0}$ & 35.90 & 52.77 & +5.07 & \\
\hline 6 & $\mathrm{G}_{50} \mathrm{MS}_{0}$ & 35.56 & 51.0 & +1.55 & \\
\hline 7 & $\mathrm{G}_{0} \mathrm{MS}_{20}$ & 30.00 & 41.50 & -17.36 & \\
\hline 8 & $\mathrm{G}_{10} \mathrm{MS}_{20}$ & 32.80 & 43.11 & -16.05 & \\
\hline 9 & $\mathrm{G}_{20} \mathrm{MS}_{20}$ & 30.66 & 51.77 & +3.08 & 5.79 \\
\hline 10 & $\mathrm{G}_{30} \mathrm{MS}_{20}$ & 29.77 & 38.60 & -23.14 & \\
\hline 11 & $\mathrm{G}_{40} \mathrm{MS}_{20}$ & 14.22 & 35.10 & -30.10 & \\
\hline 12 & $\mathrm{G}_{50} \mathrm{MS}_{20}$ & 17.33 & 37.33 & -25.66 & \\
\hline 13 & $\mathrm{G}_{0} \mathrm{MS}_{40}$ & 30.35 & 51.11 & +1.77 & \\
\hline 14 & $\mathrm{G}_{10} \mathrm{MS}_{40}$ & 32.11 & 53.30 & +6.14 & \\
\hline 15 & $\mathrm{G}_{20} \mathrm{MS}_{40}$ & 36.70 & 55.55 & +10.61 & 5.86 \\
\hline 16 & $\mathrm{G}_{30} \mathrm{MS}_{40}$ & 29.55 & 45.9 & -8.60 & \\
\hline 17 & $\mathrm{G}_{40} \mathrm{MS}_{40}$ & 26.30 & 41.18 & -18.00 & \\
\hline 18 & $\mathrm{G}_{50} \mathrm{MS}_{40}$ & 24.25 & 40.00 & -20.35 & \\
\hline 19 & $\mathrm{G}_{0} \mathrm{MS}_{60}$ & 33.20 & 51.3 & +2.15 & \\
\hline 20 & $\mathrm{G}_{10} \mathrm{MS}_{60}$ & 35.20 & 52.60 & +4.74 & \\
\hline 21 & $\mathrm{G}_{20} \mathrm{MS}_{60}$ & 38.44 & 54.40 & +8.32 & 5.91 \\
\hline 22 & $\mathrm{G}_{30} \mathrm{MS}_{60}$ & 37.00 & 50.00 & -0.002 & \\
\hline 23 & $\mathrm{G}_{40} \mathrm{MS}_{60}$ & 36.00 & 47.00 & -6.41 & \\
\hline 24 & $\mathrm{G}_{50} \mathrm{MS}_{60}$ & 35.00 & 42.00 & -16.20 & \\
\hline 25 & $\mathrm{G}_{0} \mathrm{MS}_{80}$ & 31.22 & 48.11 & -4.20 & \\
\hline
\end{tabular}


Table 3. Continued.

\begin{tabular}{|c|c|c|c|c|c|}
\hline 26 & $\mathrm{G}_{10} \mathrm{MS}_{80}$ & 32.10 & 51.40 & +2.35 & \\
\hline 27 & $\mathrm{G}_{20} \mathrm{MS}_{80}$ & 27.20 & 54.10 & +7.73 & 3.5 \\
\hline 28 & $\mathrm{G}_{30} \mathrm{MS}_{80}$ & 24.8. & 46.50 & -7.40 & \\
\hline 29 & $\mathrm{G}_{40} \mathrm{MS}_{80}$ & 23.60 & 31.20 & -37.87 & \\
\hline 30 & $\mathrm{G}_{50} \mathrm{MS}_{80}$ & 23.30 & 27.80 & -44.64 & \\
\hline
\end{tabular}

M-sand in SCC influences the compressive strength. The inclusion of GGBS and M-sand in lower percentages increases the compressive strength. In higher percentages it decreases the compressive strength. The change of percentage of compressive strength while comparing the results of control concrete with other specimens is $+3.08 \%,+10.61 \%,+8.32 \%$, and $+7.73 \%$ when M-sand added at contents of 20, 40, 60, and $80 \%$ for the GGBS content of $20 \%$. It can be seen that mix having 20\% GGBS gained high strength than the other mixes. SCC with $10 \%$ and $20 \%$ GGBS showed a high strength at 7 days and 28 days, particularly 20\% GGBS content with $40 \% \mathrm{M}$-sand content at 28 days shows a compressive strength of $55.55 \mathrm{MPa}$. Greater fineness of GGBS leads to a better strength development [17].

Moreover, from Fig. 3 it is found that the compressive strength of the mix with $40 \%$ replacement of natural sand by $\mathrm{M}$ - sand has achieved higher strength than other M-sand replacements. This is because the $40 \%$ M- sand replaced mix have optimum reaction with optimum filler capacity when it is added with $20 \%$ GGBS replaced mix. According to the experimental results the $40 \%$ replacement of $\mathrm{M}$ - sand with $20 \%$ of GGBS shows maximum compressive strengths among the other mixes. As per the work done by Nanthagopalan et al M-sand is suitable for the development of SCC due to increase in paste volume and due to high fines present in it [8]. From Fig. 4 it is found that in the adopted concrete mixes the cement replaced with 20

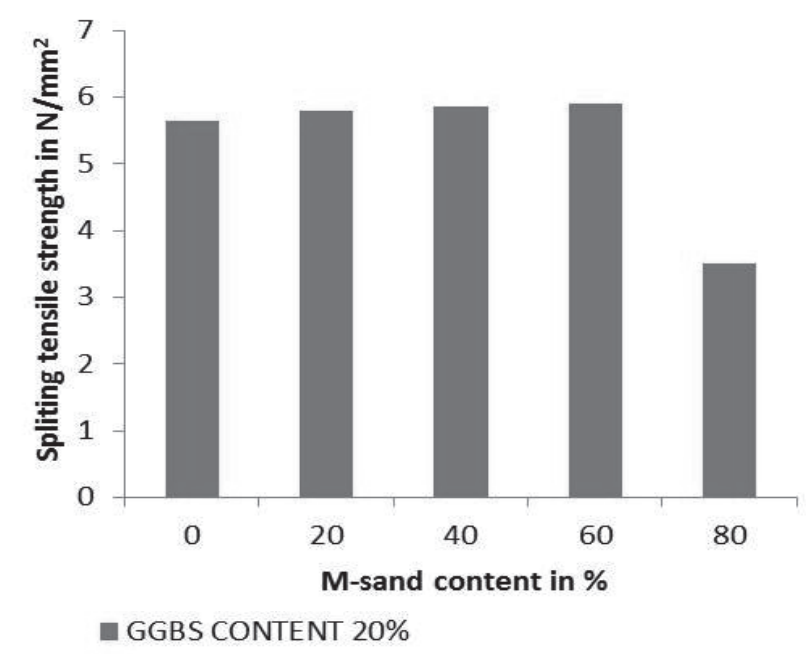

Fig. 4. Splitting tensile strength result for GGBS content of $20 \%$.
$\%$ GGBS content is the optimum content than other Proportions. From the Fig. 3 it is found that when there is further increase of the GGBS beyond $20 \%$ there is a reduction in compressive strength for other proportions of GGBS. The Fig. 3 also shows the Compressive Strength of mixes with GGBS content $20 \%$ for the various proportions of $\mathrm{M}$-sand. Among this the mix $\mathrm{G}_{20} \mathrm{MS}_{40}$ has high compressive strength than the other mixes. Nazari and Riahi found that partially replacing cement with GGBS creates a denser matrix, through this it develops strength and durability of concrete [18].

Li and Zhao observed that when GGBS was added with FA, the hydration rate of the GGBS was found to be increased at the early-age. And also it is found that there is a formation of secondary calcium silicate compound when GGBS reacts with the hydrated lime of Portland cement, in mean time it produces the homogeneous hydration products that have larger specific surface compared to Portland cement such as ettringite and hydrated lime. The hydration rate of FA was increased by the above products as they act as nucleating sites and they precipitate around FA. And also $\mathrm{OH}-$ ions and alkalis are provided into the pore fluid when GGBS hydrates and the hydration process was accelerated when glass phase of FA was affected by the reaction of $\mathrm{OH}-$ ions and alkalis with $\mathrm{SiO}_{2}[19]$

The above discussions on compressive strength reveal that the GGBS and M-sand substitution in self-compacting concrete not only helps in reducing carbon dioxide emission into the environment but also increases the strength of self-compacting concrete. The Life Cycle Impact Assessment (LICA) Analysis of High volume GGBS has been carried out by Chiu et al which suggests that the higher cement replacement level with GGBFS will give a better compressive strength/carbon footprint ratio [20].

\section{Splitting Tensile Strength}

The splitting tensile strength results are plotted in Fig. 4 for the mixes having maximum compressive strengths in each proportion of M-sand. In the various concrete mixes with $20 \%$ GGBS the increase in splitting tensile strength is $+3.66,+6.23$, and +7.52 and $+8.44 \%$ when M-sand contents of $0,20,40$ and $60 \%$ than the control specimen. From the results it is evidenced that tensile strength was improved during the GGBS and M-sand inclusion in SCC when compared to control mix without GGBS and M-sand. Because of the pozzolanic 
Table 4. SEM/EDAX Analysis results of various mixes.

\begin{tabular}{|c|c|c|c|c|}
\hline \multirow{2}{*}{ Mixture } & \multirow{2}{*}{$\mathrm{G}_{0} \mathrm{MS}_{0}$} & $\mathrm{G}_{20} \mathrm{MS}_{20}$ & $\mathrm{G}_{20} \mathrm{MS}_{40}$ & $\mathrm{G}_{20} \mathrm{MS}_{60}$ \\
\cline { 1 - 4 } composition & 50.27 & 39.52 & 40.31 & 50.55 \\
\hline $\mathrm{O}$ & 2.75 & 1.83 & 2.00 & 3.90 \\
\hline $\mathrm{Al}$ & 7.72 & 9.91 & 3.84 & 14.55 \\
\hline $\mathrm{Si}$ & 33.10 & 39.00 & 40.21 & 13.94 \\
\hline $\mathrm{Ca}$ & 3.90 & 7.26 & 12.17 & 11.74 \\
\hline
\end{tabular}

nature of the GGBS and filling ability of M-sand and fly ash, the tensile strength was improved for the concrete specimens. Mohan and Mini found similar results with Supplementary Cementitious Materials and stated that GGBS have pozzolanic nature which modifies paste characteristics and develops good transition zone. Further, strength of SCC was contributed by intense pore structure and secondary hydrated products [21].

\section{SEM/EDAX-Analysis}

This study was done on the SCC specimens with optimum proportion of GGBS (20\%) with various proportions of $\mathrm{M}$-sand. The microstructure and the elements in the concrete specimens were analyzed using the scanning electron microscope with expanded Energy dispersive X- ray Analyzer. The analyzed results are presented in Table 4.
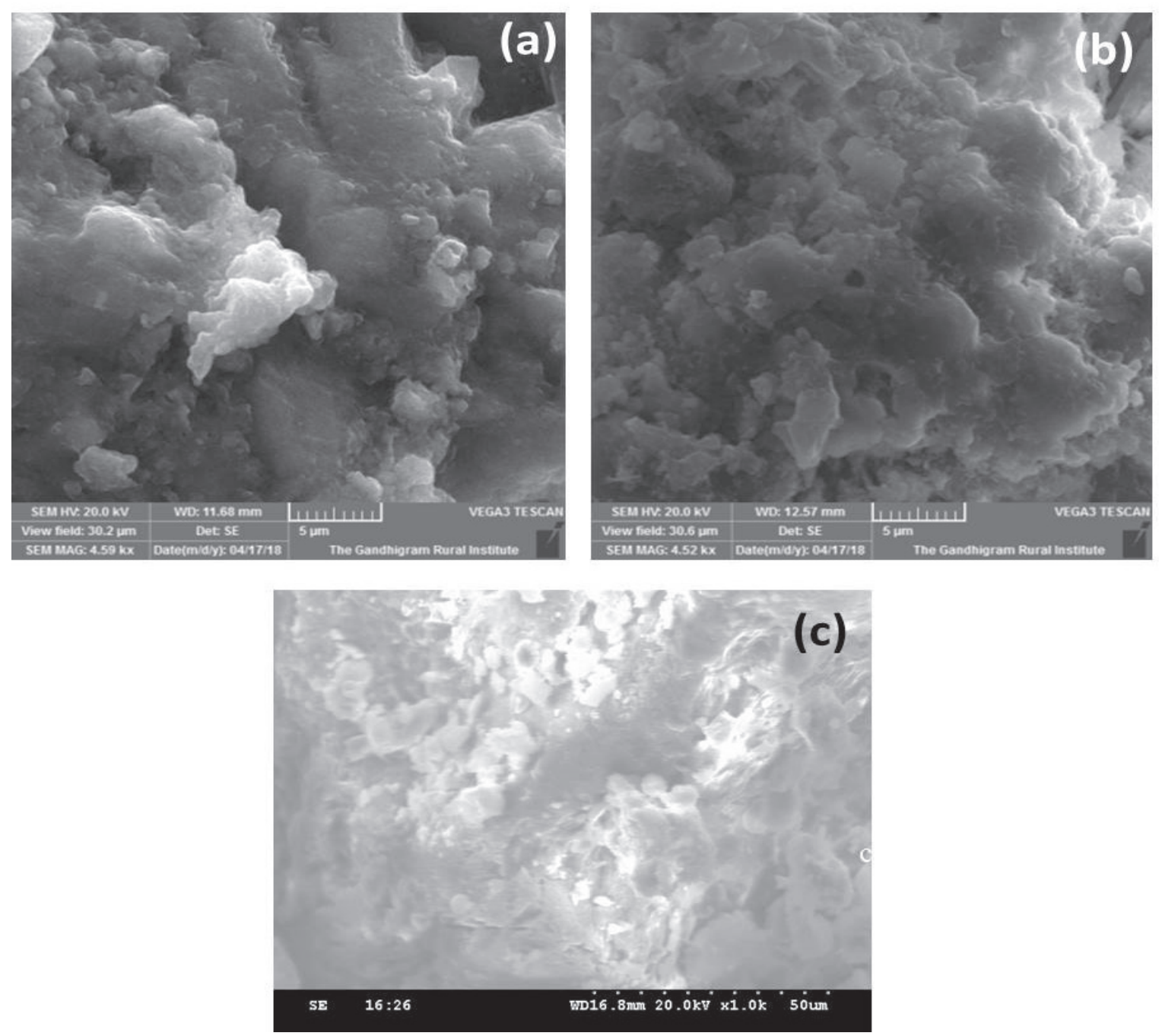

Fig. 5. a) SEM Image for Control concrete, b) SEM Image for $\mathrm{G}_{20} \mathrm{MS}_{20}$, c) SEM Image of $\mathrm{G}_{20} \mathrm{MS}_{60}$. 
In $\mathrm{G}_{20} \mathrm{MS}_{40}$ specimen the calcium content higher than that of concrete with $20 \% \mathrm{M}$-sand and $20 \%$ GGBS replacement. The improved hydration of $\mathrm{C}_{3} \mathrm{~S}$ causes increase in calcium content in the concrete. Due to this the compressive strength is high at specimen having $20 \%$ GGBS and $40 \%$ M-sand. In the SEM images the Calcium Silica Hydrate gel looks brighter in color. In Fig. 5a) the SEM image of conventional concrete specimen is in $4.59 \mathrm{Kx}$ magnification and $\mathrm{C}-\mathrm{S}-\mathrm{H}$ gel formation appears in bright color.

In Fig. 5b) the SEM image of concrete specimen $\mathrm{G}_{20} \mathrm{MS}_{20}$ is in $4.52 \mathrm{Kx}$ magnification. Compared to the conventional concrete specimen the $\mathrm{CSH}$ formation is more in the $G_{20} M_{20}$ specimen which enhances the strength than control specimen, Likewise, the hydration products are also denser. As stated by Schutter et al Blast furnace slag introduces some micro structural and chemical advantages and the composition of Blast furnace slag is found to be with almost enough $\mathrm{Ca}$ and $\mathrm{Si}$ to form the CSH gel [22]. The SEM image of concrete specimen $\mathrm{G}_{20} \mathrm{MS}_{60}$ is in x1.0K magnification in Fig. 5c). As per Yuksel when blast furnace slag is present a reaction similar to the pozzolanic reaction happens. Portland cement together with a certain amount of fly ash or blast furnace slag gives higher ultimate strength compared to plain cement [23].

Compared to the control concrete in Fig. 5a) the pores found are rare in $\mathrm{G}_{20} \mathrm{MS}_{20}$ concrete as shown in Fig. 5b). This is due to the presence of GGBS which in turn considerably reduces the quantity, mean size of $\mathrm{Ca}(\mathrm{OH})_{2}$ crystals in the aggregate-mortar Interfacial Transition Zone (ITZ) and causes the microstructure of ITZ to become more dense [24]. These effects lead to the high strength of concrete with an optimum amount of GGBS instead of Portland cement [25]. Yuksel stated that the microstructure of concrete having GGBS is altered from PC (Portland cement) concretes because of additional reactions with GGBS [23]. In Fig. 5c). $\left(\mathrm{G}_{20}\right.$ $\mathrm{MS}_{60}$, because of the increased replacement of $\mathrm{M}$-sand content the homogeneity of the concrete is reduced and the number of pores seen is more.

\section{Conclusions}

To summarize: The following conclusions have beeen drawn:

GGBS, which is both cementitious and pozzolanic over conventional cement concrete material, may be added to enhance the rheological characteristics of concrete. It allows very high replacement of cement and provides many benefits over conventional cement concrete. In the adopted concrete mixes, the cement replaced with $20 \%$ GGBS content is the optimum content than other Proportions. Among the various mixes $\mathrm{G}_{20} \mathrm{MS}_{40}$ has high compressive strength than the other mixes. The achieved compressive strength at 28 days was $55.55 \mathrm{MPa}$. From the SEM results, it is found that the GGBS consists of rough and dense microsized angular particle. The inclusion of mineral admixtures like GGBS and fly ash increases the paste volume. This increase in paste volume reduces the friction between the aggregate and paste particles and hence the fluidity of the mix is good when the GGBS content increases. The addition of $\mathrm{M}$-sand beyond $80 \%$ will affect the flowability characteristics of SCC. All proportions of GGBS enhance the splitting tensile strength. The splitting tensile strength results show that there is an increase in tensile strength with the inclusion of GGBS and M-sand in SCC compared to control mix. But there is a reduction in tensile strength beyond $60 \%$ of $\mathrm{M}$-sand in the $20 \%$ GGBS replaced specimens. Thus, it is proposed that GGBS can be used in SCC as a pozzolanic material. Hence it enhances environmental safety. And M-sand can also be a good substitute for natural sand in the production of SCC. The sustainability of the natural resources is ensured by using $\mathrm{M}$-sand. The goal of sustainable environment and reduced carbon emissions can be achieved by replacing the cement content in self-compacting concrete with industrial waste GGBS and natural sand with M-sand.

\section{Acknowledgements}

Author A. Leelavathi would like to acknowledge the financial support provided by Program TEQIP-III, implemented by the National Project Implementation Unit (NPIU) of the Ministry of Human Resource Development, Government of India.

\section{Conflict of Interest}

The authors declare no conflict of interest.

\section{References}

1. DU Q., HUANG Y., XU Y., BAI L., BAO T., WANG $\mathrm{H}$. Benefit allocation in the construction supply chain considering carbon emissions. Polish Journal of Environmental Studies, 28 (5), 3697, 2019.

2. GANESHPRABHU P., CHANDRASEKARAN P., FARZANA A.S. Engineering Behaviour of Sustainable Concrete with Steel Mill Scale. Polish Journal of Environmental Studies, 30 (2), 1129, 2020.

3. WU P., WANG C., ZHANG Y., CHEN L., QIAN W., LIU Z., LI L. Properties of cementitious composites containing active/inter mineral admixtures. Polish Journal of Environmental Studies, 27 (3), 1323, 2018.

4. AARTHI K., ARUNACHALAM K. Durability Studies on Fibre Reinforced Self Compacting. Journal of Cleaner Production, 2017.

5. DADSETAN S., BAI J. Mechanical and microstructural properties of self-compacting concrete blended with metakaolin, ground granulated blast-furnace slag and fly ash. Construction and Building Materials, 146, 658, 2017. 
6. DINAKAR P., SETHY K.P., SAHOO U.C. Design of selfcompacting concrete with ground granulated blast furnace slag. Materials and Design, 43, 161, 2013.

7. RAJU S., DHARMAR B. Studies on flexural behavior of reinforced concrete beams with copper slag and fly ash. Structural Concrete, 21 (1), 107, 2020.

8. NANTHAGOPALAN P., SANTHANAM M. Fresh and hardened properties of self-compacting concrete produced with manufactured sand. Cement and Concrete Composites, 33 (3), 353, 2011)

9. KARMEGAM A., KALIDASS A. Reusing granite sawing waste in self-compacting concrete with polypropylene fiber at low-volume fractions. Structural Concrete, 20 (2), 766, 2019.

10. PRAKASH R., THENMOZHI R., RAMAN S.N. Mechanical characterisation and flexural performance of eco-friendly concrete produced with fly ash as cement replacement and coconut shell coarse aggregate, 18 (2), 131, 2019.

11. IS:12089-1987. Specification for granulated slag for the manufacture of Portland slag cement. Bureau of Indian Standard, New Delhi, 1, 1987.

12. Bureau of Indian Standards (BIS). Concrete Mix Proportioning- Guidelines. Bureau of Indian Standards (BIS), Second Rev (January), 1, 2019.

13. EFNARC. The European Guidelines for Self-Compacting Concrete. The European Guidelines for Self Compacting Concrete, (May), 63. Retrieved from http://www.efnarc. org/pdf/SCCGuidelinesMay2005.pdf 2005.

14. VIVEK S.S., DHINAKARAN G. Fresh and hardened properties of binary blend high strength self compacting concrete. Engineering Science and Technology, an International Journal, 20 (3), 1173, 2017.

15. RAMANATHAN P., BASKAR I., MUTHUPRIYA P., VENKATASUBRAMANI R. Performance of selfcompacting concrete containing different mineral admixtures. KSCE Journal of Civil Engineering, 17 (2), 465, 2013.

16. SHEEN Y.N., LE D.H., SUN T.H. Greener self-compacting concrete using stainless steel reducing slag. Construction and Building Materials, 82, 341, 2015.

17. A.M NEVILLE. Properties of concrete, $4^{\text {th }}$ Edition). Pearson Education, New Delhi, India, 2003.

18. NAZARI A., RIAHI S. $\mathrm{TiO}_{2}$ nanoparticles effects on physical, thermal and mechanical properties of self compacting concrete with ground granulated blast furnace slag as binder. Energy and Buildings, 43 (4), 995, 2011.

19. LI G., ZHAO X. Properties of concrete incorporating fly ash and ground granulated blast-furnace slag. Cement and Concrete Composites, 25 (3), 293, 2003.

20. ONN C.C., MO K.H., RADWAN M.K.H., LIEW W.H., NG C.G., YUSOFF S. Strength, carbon footprint and cost considerations of mortar blends with high volume ground granulated blast furnace slag. Sustainability (Switzerland), 11 (24), 2019

21. MOHAN A., MINI K.M. Strength and durability studies of SCC incorporating silica fume and ultra fine GGBS. Construction and Building Materials, 171, 919, 2018.

22. SCHUTTER G. DE BARTOS P.J.M., DOMONE P., GIBBS J. Self-Compacting Concrete, $1^{\text {st }}$ edtion) Whittles Publishing, Scotland, UK, (2008.

23. YUKSEL I. Blast-furnace slag. Waste and Supplementary Cementitious Materials in Concrete: Characterisation, Properties and Applications. Elsevier Ltd, 2018.

24. GAO J.M., QIAN C.X., LIU H.F., WANG B., LI L. ITZ microstructure of concrete containing GGBS. Cement and Concrete Research, 35 (7), 1299, 2005.

25. ZHAO H., SUN W., WU X., GAO B. The properties of the self-compacting concrete with fly ash and ground granulated blast furnace slag mineral admixtures. Journal of Cleaner Production, 95, 66, 2015. 